\title{
Korunk gyermekeinek érzelmi élete - az iskolában folyó érzelmi nevelés
}

\author{
Jávorné Kolozsváry Judit
}

pszichológus, nyugalmazott föiskolai docens

\begin{abstract}
A tanulmány a fiatal generációk érzelmi életének, érzelmi intelligenciájának fejlődési folyamatával foglalkozik. Azzal, hogy e folyamat egytényezős-e vagy multikauzális; vajon a családi és az intézményes nevelés elegendő impulzust ad-e a gyermekek kívánatos érzelmi fejlődéséhez. Lehetséges-e, hogy az Y-, a Z-generáció olyan személyiségsajátosságokat hordoznak, amelyek falat húznak köréjük s akadályt képeznek a szülői/nagyszülői és a fiatal generációk kommunikációja között? A tanulmány ismerteti a szeretetnyelv-elméletet, szól a kötődés és a szeretet személyiségformáló erejéröl, ajánlást ad arra nézve, milyen módon segítheti a család, az óvoda, az iskola a gyermekek többszörös intelligenciájának fejlödését, szem elött tartva az egyes intelligenciafaktorok egymásra gyakorolt hatását. Sor kerül két eset ismertetésére és értelmezésére is. Végül az olvasó választ kaphat a tanulmány elején feltett kérdésekre.
\end{abstract}

Kulcsszavak: többszörös intelligencia, érzelmi fejlödés és az agy müködése, érzelmek és tanulás, kötödés, szeretetnyelvek

Sokak által sokszor emlegetett, már-már közhellyé váló kérdésre keresünk választ ebben a tanulmányban:

- Van-e szembetűnő, érzékelhető, talán mérhető különbség „korunk gyermekei” és korábbi nemzedékek érzelmi élete között?

- Ha van, mi az oka: több tényező kölcsönhatása vagy egy tényező áll a háttérben?

- Az iskola/óvoda - mint gyermekeink nevelésének, oktatásának intézményes színtere - megfelelő módon és minőségben biztosítja-e vagy biztosíthatja-e a gyermekek érzelmi nevelését?

- Osszeegyeztethető, vagy megosztható ebben a kérdésben az intézmény és a család feladata, felelőssége?

A téma kibontásában az intelligencia, a többszörös intelligencia, az interperszonális és az érzelmi intelligencia értelmezése, ezek jelentősége, valamint az egyén fejlődése, társadalmi beilleszkedése, testi-lelki egészsége, „well-being” érzése a rendező elv, miközben - remélhetőleg - sikerül elkerülni a gyermekekre vagy a felnőtt társadalomra vonatkoztatható olyan általánosításokat, mint például „ezek (sic!) mások”, „nem lehet őket nevelni”, „ezek más bolygóról jöttek, mi nem értjük őket” (idézet pedagógusokkal, szülőkkel folytatott beszélgetésekből).

\section{Az érzelmek, az érzelmi intelligencia funkciója az ember életében}

Az intelligencia fogalmának és tartalmának meghatározása, de még körülírása is, eléggé nehézkes és koronként változó. Az intelligenciát szokás képességeknek tekinteni, általános megértési és értelmi képességként kezelni, amelyben fontos tényezők: ítéletek alkotása, a hétköznapi értelmesség, a gyakorlati érzék, a kezdeményezésre való képesség, az alkalmazkodási képesség megléte, színvonala, fejlettsége (Binet és Simon, 1905). Ezek a képességek függenek az előzőleg szerzett tapasztalati anyagtól, a gondolkodás fejlettségétől és a gyakorlattól is. Látjuk, hogy ez a klasszikusnak tekinthető meghatározás sokféle összetevőt ölel fel, de nem mondja ki, hogy tevékenységünket, 
cselekvéseinket, döntéseinket nagymértékben meghatároznák érzelmeink. Óhatatlanul felmerül a kérdés, valóban csak ennyi az intelligencia? Vajon az életben elért, elérhető sikeresség, jó életvezetés, lelki egyensúly, fejlett alkalmazkodási képesség, a „well-being” mögött vannak-e más aspektusú személyiség-elemek, és ezeknek van-e helyük az intelligenciában?

Howard Gardner (1983) szerint az intelligencia egyfajta személyiségtényező, amely különböző ismeretek alkalmazására, cselekvésekben, tevékenységben megnyilvánuló felhasználására tesz képessé. Nála hangsúlyozottan megjelenik az intelligenciáról való gondolkodás két alapeleme: ismeret és tevékenység, amelyeket az alkalmazás képessége füz össze. Gardner úgy véli, az intelligencia az agy elemző és megkülönböztető képessége, amelynek milyensége az ember egyik sajátossága, az egyén társadalmi helyének és besorolásának egyik mutatója $s$ egyben lehetősége. lly módon a gardneri intelligenciát az alábbi képességekkel lehet jellemezni, hozzátéve hogy az ezen képességek helyes használatára való „készültség” különösképpen fontos:

- átfogó látásmód

- analitikus képesség

- emlékezet

- mérlegelés- és döntésképesség

- rövid- és hosszútávú gondolkodás.

Ez a „készültség” az ember lappangó lehetősége a helyes út keresésére és megtalálására, amelyre akkor van valódi esélye, ha nem csupán kognitív, hanem erkölcsiérzelmi intelligenciával is rendelkezik. Ebben a kontextusban vizsgálódva, az intelligencia megnyilvánulási területei lehetnek:

- verbális-nyelvi (beszéd, írás, nyelvi kultúra, szókincs),

- matematikai-logikai (érvelés, ok-okozati összefüggés, számok világa, rendszere),

- vizuális-téri (a látvány esztétikuma, a környezet téri elhelyezkedése, a tér ésszerü használata, berendezése, színek és formák harmóniája),

- testi-kinetikus (testi-mozgásos tevékenységek, a testi mozgások gazdaságos, összerendezett használata, a kéz finommotorikája),

- interperszonális:

- önismereti intelligencia,

- szociális, kapcsolati intelligencia,

- zenei-auditív (hangok, ritmus, hangszín, beszédritmus),

- metakognitív:

- foglalkozás önmagammal: ki vagyok én, honnan jövök, hová tartok, mi a dolgom,

- filozófiai kérdések: mi a helyes, mi a jó, mi a világ, van-e rendező elv, mi az ember dolga a világban.

E gardneri (1999) felosztásban több újszerü elem jelenik meg. Az újszerüség maga az intelligencia multiplikálása, a többszörös intelligencia fogalmának bevezetése gondolkodásunkba. Ez az emberi intelligencia differenciáltságának, sokszínúségének és egyéni színezetének olyan felismerése, ami alapjaiban módosította a nevelésoktatásról, a munkavégzésről, a munkavállalásról és a munkáltatói viselkedésről, az ember kapcsolatairól szóló elképzeléseket és gyakorlatot. Számos iskolai tantárggyal összefüggésben dolgoztak ki koncepciót, metódust pedagógusok, amely koncepciók azt célozták, hogy az egyes tantárgyak kerüljenek összhangba a többszörös intelligencia létezésével és fejlesztésével, illetve azt, hogy a többszörös intelligenciáról való tudás hasznosuljon az egyes tantárgyak ismeretanyagának elsajátításában és gyakorlati hasznosításában. 
A gardneri elmélet - tárgyunk szempontjából különösen - fontos eleme az interperszonálisintelligencia-faktor. Gardnereztafaktortkomplexképességegyüttesként kezeli: egyrészt fontosnak és erőteljesen fejleszthetőnek írja le az önismereti intelligenciát, másrészt ugyanilyen jelentőségünek tarja a szociális, kapcsolati intelligenciát. Az önismereti intelligencia utat képez a szociális, kapcsolati intelligenciához, ugyanakkor a kettő kölcsönhatásba kerül egymással. Az interperszonális intelligencia mindkét faktora mintegy kooptálja az érzelmi intelligenciát (a képességet és a tudást a saját és mások - érzelmeinek felismeréséhez, megkülönböztetéséhez, identifikálásához, valamint ezek beépítését mind az önszabályozásba mind humán kapcsolataink kezelésébe).

Az interperszonális intelligencia jelentőségére kiterjedt és alapos longitudinális vizsgálatok tapasztalatai hívták fel a figyelmet. 95 egyetemi hallgató életpályáját követték nyomon kutatók (Felsman és Vaillant, 1987), érett felnőtt korukig. Megfigyelték és elemezték magánéletüket, annak jelentős állomásait, valamint karrierbeli előrehaladásukat, karrierépítési módozataikat, sikereiket. Természetesen mérték a résztvevők sokféle intelligenciafaktorát. A vizsgálati eredmények megdöbbentőek és egyértelmüek voltak: sokan extrém magas értelmi intelligenciával, de az általánosnál alacsonyabb vagy általános szintű érzelmi intelligenciával rendelkezve nem túl sikeres beosztottjai voltak átlagos értelmi, de magas érzelmi intelligenciájú vezetőknek. A sikerességet a megfigyelt és nyomon követett életutakon döntően az befolyásolta, hogy melyikük volt képes felismerni, döntéseiben, emberi kapcsolataiban a helyzethez igazodva alkalmazni saját és mások érzelmeit, hogyan kezelte konfliktusait. Melyikük volt képes megítélni, hogyan viszonyuljon önmaga és mások vágyaihoz, motivációjához, az élet nehézségeihez.

Az érzelmi intelligencia tehát lehetőség az érzelmek percepciójára, valamint arra, hogy az egyén hozzáférjen saját és mások érzelmeihez, vagy éppen generálja azokat. A másik ember érzelmeit visszatükrözve segíti a másik embert érzelmeinek felismerésében, identifikálásában és szabályozásában. Ezzel elősegíti a másik ember érzelmi és egyéb intellektuális fejlődését. Az érzelmi intelligencia négy alapvető mentális folyamatból tevődik össze:

- az érzelmek percepciója, azonosítása, megnevezése;

- a gondolkodás érzelmi alapozása;

- a helyzetek és emberek érzelmi megértése;

- érzelmi vezérlés (önmagunké, másoké).

Mindezek segítségével lehetünk képesek önmagunk és mások megnyugtatásának elősegítésére, az érzelmi komfort előhívására és fenntartására. Ily módon az érzelmi intelligencia szervesül az interperszonális intelligencia faktoraiba, ezért szükséges erről gondolkodnunk.

\section{Az érzelmek, az érzelmi intelligencia fejlődésének sajátosságai, törvényszerűségei}

\section{Érzelmek és az agyi fejlődés}

A magzati életben természetesen minden szerv fejlődése egyaránt fontos, jelentős. Jelen témánkban a magzati fejlődési folyamatokat az érzelmek és az agy kapcsolatának rövid áttekintésére célszerű korlátozni.

Az agy egyes részeinek fejlődése időben eltérően zajlik. Az agy ősi részei - agytörzs, kisagy, középagy - korábban fejlődnek, míg a féltekék és az agykéreg (mint 
az agy evolúciós folyamatának újabb termékei) később. Ennek következtében a korábban fejlődő agyi részek müködése a magzati élet korábbi időszakaiban kezdődik, mint a neocortexé. Az érzelmi fejlődés szempontjából jelentős hypothalamus és ennek része, az amygdala, korábbi időszakban kezd tanulni, mint az agykéreg, a tudat hordozója. Ily módon olyan tudás birtokába is jut - például megtanulja és elraktározza az anya által a magzatnak közvetített érzelmeket, indulatokat, az anya magzatára irányuló vitális ösztönzéseit: „élj és légy egészséges”, vagy éppen: „nem kívánom, hogy élj!” - amelyröl az agykéreg nem tudhat, mert még nem alakult ki (Hidas, Raffai és Vollner, 2013). Ezért az amygdalát, „minden tudások tudójának” szokás tekinteni, vagyis a mindentudó amygdala olyan módon képes irányítani érzelmeinket és cselekedeteinket, hogy azok eredetét, okát nem ismerjük (fel). (Bárki átélhette azt az élményt, hogy valamelyik gyors, impulzusszerü reakcióját követően, mintegy rácsodálkozva arra, azt mondta „nem tudtam, hogy erre is képes vagyok, mintha nem is én lettem volna”.) Az amygdala szoros összeköttetésben van a viselkedést szabályozó homloklebennyel: érzelmi-indulati impulzusai a homloklebenybe jutva befolyásolják a homloklebenyben lejátszódó döntési folyamatokat. Ily módon manifesztálódnak az indulatok által vezérelt, gyakran érthetetlen viselkedéses válaszok a külvilág ingereire (Fromm, 2001).

\section{Érzelmek és tanulás}

Tanulhatók-e az érzelmek? Avagy: tudjuk-e befolyásolni, mintegy rábírni az agyunkat érzelmek átélésére, tanulására? Taníthatók az érzelmek? Tanítható, fejleszthető az érzelmi intelligencia, melynek életvezetésünkre, személyiségünkre, kapcsolatainkra nézve olyan nagy hatása van?

Az agy tréningje, tanítása révén elérhető érzelmeink felismerése, kontrollja (Fromm, 2001). Gyermekkorban igen jó hatásfokkal tanítható mindenki arra, hogy érzelmeit megnevezze. Például a 2-3 éves kisgyermek „hisztizése” esetében dühöt, haragot, a tehetetlenség feszültségét, félelmet, szorongást, kétségbeesést élhet meg. Ha azt akarjuk, hogy érzelmi intelligenciája fejlődjön, akkor - a „roham” csillapodását követően - a felnőttnek meg kell neveznie, kérdésekkel rá kell vezetnie a gyermeket az éppen aktuálisan átélt érzelmeire. A „Ne hisztizz!”, „Hagyd abba a hisztizést!” felszólítások, vagy a folyamatnak lekicsinylő megjegyzésekkel történő kísérése - „Na, rájött a hiszti!”, „Na, hisztizz magadnak!" stb. - akadályozzák a gyermeket érzelmeinek, indulatainak azonosításában, megnevezésében, ezek kognitív felismerésében. Már a 2-3 éves gyereknek is segít érzelmei, indulatai felismerésében, ha megfelelő kérdésekkel, egyszerü, rövid magyarázatokkal kezeljük indulatainak kiömlését. Például „Félsz valamitöl?”, „Haragszol?”, „Dühös vagy?” stb. kérdések, kiegészítve célzott beszélgetéssel arról, hogy minden embernek vannak érzései, érzelmei, amelyek jónak, vagy éppen rossznak minősülnek a környezet szemében, és hogy jogában áll mindenkinek megélnie az érzelmek/indulatok széles skáláját, de nincs joga másokat bántalmazni. (Tegyük fel toporzékolhat, de nem üthet, haraphat, rúghat meg másokat. Vagy: idősebb gyerekeknél: sírhat, de ne használjon obszcén szavakat.) Fontos tudnia a gyereknek, hogy érzelmeivel együtt szereti őt az anyja, az apja, ezek miatt nincs része el- és megítélésben, de azt is kell tudnia, hogy tőle magától függ, mit kezd ezekkel az érzelmekkel. Annak a jelentős tudásnak kell birtokába juttatni a (kis)gyermeket, hogy joga van sírni, szomorúnak, dühösnek, haragosnak, féltékenynek, irigynek vagy éppen résztvevőnek, együttérzőnek stb. lennie, egyszóval: joga van az érzelmeihez, éppúgy, mint mindenki másnak. Ez az út vezet el a gondolkodás érzelmek általi befolyásoltságához (az érzelmi intelligencia második alapvető eleme), majd a másoknak és önmagának, valamint az élethelyzeteknek az érzelmi megértéséhez (harmadik alapvető elem). Talán nehéznek 
vagy ijesztőnek találhatja ezt a folyamatot a szülő, a pedagógus, attól tartván, hogy a gyermek indulatos lesz, csak indulatvezérelt viselkedést fog tanúsítani, önfegyelem, önszabályozás nélkül. E félelmek eloszlatására gondoljuk végig a következőt: az érzelmi intelligencia egyik alappillére az önismeret. Mindennapi használatra lebontva az önismeret legfontosabb elemei a következők:

- ismerni a saját

- érzelmeket,

- vágyakat,

- motivációkat,

- felismerni az aktuális élethelyzet jellegét

- egyeztetni ezeket

Ez vezet el:

- az önkontroll,

- az önuralom,

- az önirányítás képességekhez.

Ez a képességegyüttes megkönnyíti a stresszhelyzetek, konfliktushelyzetek felismerését, kezelését, elviselését. Segíti a megküzdést és azt, hogy az érzelmek egyensúlyba kerüljenek, ne váljanak dominánssá a negatív érzelmek, létrejöhessen egy kvázi érzelmi-indulati egyensúly, vagyis: fejlődjön ki a gyermekben az indulatkontroll. Ezek révén alakulhat az önmotivációs képesség, amelynek alkotóelemei:

- szívósság,

- szorgalom,

- nehézségeknek ellenálló magatartás,

- reménnyel teli attitüd (nem feladni fontos dolgokat),

- empátia: a másik (a többi) emberhez való viszonyulás.

Az empátia legfontosabb alapelemei

- az együttérzés (még a számunkra nem szimpatikus emberekkel is, ha azok bajban vannak vagy szomorúak)

- mások érzelmeinek elképzelése (ami nem azonos a projekcióval, vagyis azzal, hogy én az ő helyében mit éreznék, mit tennék, hanem annak megjelenítése, hogy a másik ember az ő sajátos, csak őt jellemző személyiségével mit érez adott helyzetben).

Ez lesz alapja a másokkal való sikeres együttmüködésnek, a jó konfliktuskezelésnek, a sikeres kapcsolatteremtésnek. Mindennek előfeltétele a saját élmény megélése, saját érzelmek keletkezésének, kiteljesedésének majd megnyugvásának végigélése. Ez teszi lehetővé a másik ember érzelmeinek elképzelését, felismerését, kezelését, a másokkal való együttélést.

Az emocionális fejlődésnek/tanulásnak társas feltételei vannak, olyan szociális folyamatokról van szó, amelyek csak másokkal való viszonyban alakulhatnak. Ilyen viszonyok szülőkkel, testvérekkel, majd pedagógusokkal való együttműködésben és kortársi kapcsolatokban fejlődnek. Ezek sikeressége vagy gyengeségei befolyásolják az optimális érzelmi fejlődést. Az emocionális fejlődéshez szükséges feltételek: a kötődés és a szeretet.

A kötődés az első emocionális kapcsolat egy másik emberrel, többnyire az anyával. A jó kötődés biztonságot, védelmet, ösztönzést, támogatást, elismerést jelent az egyén számára, ugyanakkor feltétele a fejlődésnek. Harlow (1959) és Spitz (1967) közismert vizsgálatai (idézi Mérei és V. Binét, 2006), megfigyelései, kísérletei egyértelműen bizonyították, hogy a gyermek optimális fejlődéséhez szükséges az abszolút biztonság, a táplálás, az ösztönzés, a gyermeket fejlődési „eredményeiért” őt szeretettel, szeretet-megnyilvánulásokkal jutalmazó felnőtt. A fejlődés megtorpanását, stagnálását, majd regresszióját eredményezi a bizonytalan kötődés, illetve a kötődés hiánya. 
A szeretet magas hőfokú érzelem, ami nélkül megfelelő, optimális személyiségfejlödés aligha létezik. Fromm (2012) a szeretetnek több fajtáját különbözteti meg, amelyek közül részletesebben az anyai és apai szeretettel foglalkozunk.

Az anyai szeretet (az elnevezés onnan származik, hogy ez a szeretetfajta többnyire az anyákat jellemzi) legföbb ismérve a feltétel nélküliség, a gondoskodás, az állandóság és a biztonság nyújtása. Feltétlen, mert semmiféle feltételhez nem köthető. „Nem akkor és azért szeretlek, ha és amikor jó leszel, nem kell szeretetreméltónak lenned, elég, hogy vagy." Az anya mindig és minden körülmények között, állandó és állhatatos szeretettel veszi körül gyermekét, akárhogyan is fejlődik vagy nem fejlödik a gyermek. Az anyai szeretet feltétel nélkülisége egészen pontosan azt jelenti, hogy nincs olyan küszöb, amelyet át kell lépni ennek a szeretetnek az elnyeréséért. Nincs olyan feladat, amit ezért teljesíteni kell, nincs olyan fejlődési kívánalom, aminek ezért eleget kell tenni. Vagyis: nincs „ha jó leszel, majd szeretlek”, nincs „téged nem lehet szeretni, benned semmi szeretnivaló nincs, javulj meg”, nincs „fogadj szót, akkor majd szeretlek”, de van: „azt akarom, hogy viselkedj 'normálisan', hogy fejlődj, mert ez a te érdeked - de ha nem sikerül mindig, vagy elég jól, vagy sehogy, én akkor is szeretlek. Az én állhatatos, biztonságot adó szeretetem mindenkor a tiéd".

Amiért nem kell tenni semmit, azért nem is lehet. A gyermek hiába igyekszik jónak lenni, szorgalmasnak lenni, kedvesnek lenni, ha nincs meg a feltétel nélküli anyai szeretet, azt a gyermek nem tudja előidézni. Ha van ilyen szeretet az anyában, akkor a gyermeké az élet minden szépsége és boldogsága. Ha nincs, és a gyermek környezetében nincs olyan személy, aki képes anyai szeretet szerepre, akkor az élet boldogsága hiányos, csonka lesz a gyermek számára. Az anyai szeretet olyan biztonságot jelent a gyermeknek, amelyből felnőtté érve kirepülhet. Anyai szeretet hiányában (amelyet nemcsak az anya adhat, hanem erre képes más felnőtt is) a gyermek nem tudja megtanulni a szeretetet, ami egyik alappillére a szociális intelligenciának, ily módon hiányos lesz önismerete, a saját és mások érzelmeinek megértési képessége, az ezekre épülö önirányítás, önszabályozás, önkontroll és önuralom. De még a megküzdési képesség is csökkent mértékü lehet, mert a gyerek nem érzi és nem tanulja meg saját életének fontosságát. A gyermek érzelmi intelligenciája az anyai jelenlétben fejlődhet, tehát a „minőségi idő” együtt töltése alapvető feltétele az érzelmi intelligencia alakulásának.

Természetesen az anya támaszt követelményeket a gyermekkel szemben, de ezek nem feltételei a szeretet elnyerésének. (Megtanítja neki és megköveteli tőle az együttélés alapszabályait, szociális szokásokat, lehet haragos, ha a gyermek ezeket a szabályokat áthágja, akár megbüntetheti a gyermeket, de nem vonja vissza tőle a szeretetét.)

Joggal merül fel a kérdés, hogy mit tehet az az anya, aki a szeretetnek ezt a feltétel nélküli fajtáját nem tudja adni a gyermeknek. Az eddigiekből világosan kitűnik, hogy a szeretet tanulható, nem velünk született képességünk. Az anya-gyermek kapcsolat alakulása során előbb-utóbb megtanulhatja az anya és gyakorolhatja gyermekével kapcsolatban ezt a fontos szeretetfajtát.

A másik felmerülő kérdés: tévedhet-e az anya, aki képes anyai szeretetet érezni/ adni? Minden bizonnyal igen. A feltétel nélkülinek látszó szeretet átcsaphat nárcizmusba, amikor is az anya valójában önmagát „imádja” a gyermekben. Ilyenkor eltünik a feltételnélküliség és belép az az állapot, amikor „azért szeretlek, mert olyan vagy mint én, mert rám hasonlítasz, mindig maradj ilyen, és akkor szeretni foglak". Vagy átlényegülhet a kezdetben valódi feltétel nélküli szeretet a viszonzás elvárásába („Nem azért szültem, hogy öregségemre egyedül maradjak!"). Sajnálatosan az sem kizárt, 
hogy a rosszul értelmezett feltételnélküliség konzerválja a gyermek gyengeségeit, hiányosságait („Én nem tiltok semmit, mert akkor sírni fog, én nem kívánok tőle semmit, majd rájön magától..."). Ilyen esetekben mintegy elcsúszik a folyamat: nem törődünk a gyermek fejlődésével, érdekeivel, sőt, elzárjuk őt a fejlődési lehetőségektől, ily módon láncolva őt magunkhoz.

Az apai szeretet nagyon is más. Az apa (ezt a fajta szeretet is közvetítheti más személy, de többnyire az apák szokták) feltételeket támaszt a gyermek szerethetőségét illetően: „Szeretem, ha már lehet vele játszani, ha jól viselkedik, ha szép, ha okos, ha szófogadó, ha sikeres a tanulásban, sportban, szerelésben, ha büszke lehetek rá...”. Az apai szeretet elváró, követelő és ösztönző: „Azt akarom hogy bátor légy, okos, talpraesett, ne légy lekvár". Az apa tulajdonságokat, készségeket preferál, amelyek elsajátítására ösztönzi a gyermeket. Az apa érdeklődésre, kíváncsiságra, felfedezésekre, kihívások teljesítésére, kalandvágyra biztatja a gyermeket. Ilyen ösztönzések és az anya nyújtotta biztonságérzet nélkül a világ lassabban változna körülöttünk. $A z$ apai szeretet orientál, értéket és normát szab, ezzel jelentősen befolyásolja a gyermek értékítéletét és karrierépítési terveit. (A felfedező útra induló fiút az anya meleg ruhákba bugyolálná, míg az apa azt mondja: „Légy bátor, sikeres, légy eredményes!”). Természetesen nem minden apa képes erre a szeretetre, van, aki éppenséggel anyai szeretetet tud adni a gyerekének. Amennyiben a szülők között „szerepcsere” zajlik, nincs semmi baj, a gyerek mindkét szeretetfajtában részesül.

Az önismerethez, az érzelmek megéléséhez, identifikációjához, mások érzelmeinek felismeréséhez, a kapcsolatteremtő képességek és készségek fejlődéséhez, a jó alkalmazkodóképesség alakulásához a gyermeknek - Fromm szerint - mindkét fajta szeretetre szüksége van.

Mi történik azonban, ha egyáltalán nincs anyai-apai szeretet, például ha a gyermek állami gondoskodásban él, és viszonylag későn (három éves kora után, egyes szerzők szerint 12-18 hónapos koránál később [Maccoby, 1980, idézi Pulay, 1997]) kerül nevelőszülőkhöz vagy fogadják örökbe? Akkor hogyan fejlődnek érzelmei, érzelmi intelligenciája? Szerencsés esetben a szülök hiányában kötődés alakul ki valamelyik gondozónő és a gyermek között, ezért van esély pozitív irányú érzelmi fejlődésre. A gyermek megtapasztalhat biztonságérzetet, intimitást, személyének fontosságát, ezek az érzések, tapasztalatok fogják képezni az érzelmi intelligencia, az önismereti és a kapcsolati intelligencia alapjait. Amennyiben a kötődés létrejötte lehetetlen, sajnálatosan nagyon kicsi az esély ilyen fajta alapok elsajátítására, következésképpen a további építkezésre.

Mi történik, ha egyszülős családban él a gyermek, és ezért hiányzik valamelyik szeretetfajta átélési lehetősége? A gyermekkel maradó szülő többnyire megpróbál mindenben két szülő helyett viselkedni; mindkét szeretetfajtát legalább időnként megadni a gyermeknek. Vajon lehet ezt huzamos időn keresztül jól csinálni? Valószínüleg nem. És valószínúleg nem is kell. Nem kell úgy tenni, mintha egy személyben megtestesíthető lenne az apai és az anyai szeretet, mert a gyerek számára a szülő hiteltelenné válik. A tapasztalatok azt mutatják, jobb elvállalni, hogy egy szülő egyféle módon tud és képes szeretni, a másik szülői szeretet-szerepet nem tudja betölteni. A gyerek számára természetesen a hiány létezik, de létezik az is, amit a meglévő szülő ad és adhat. Hazai gyakorlatunkban zömében az apai elváró, ösztönző szeretet hiánya következik be, ami a gyermekek érzelmi-akarati intelligenciájában, a figyelem összpontosításában, a célképzet megalkotásában okozhat deficitet.

Valamelyik szülő halála nyilvánvalóan súlyosan érinti a gyermek érzelmi, szociális fejlődését, befolyásolja mind önismereti, mind társas kapcsolati képességeit. Mind 
valamelyik szülő halála, mind válás esetén akár törvényszerünek is tekinthető módon elhatalmasodhat a szorongás a gyermekben, amely ahhoz a fantáziához kötődik, hogy a halál, a válás az ő meg nem felelésén, „rosszaságán” múlt. Ilyen esetekben bűntudat kapcsolódik a család felbomlásához, amely hibás önértékeléshez, önismerethez és következményesen elégtelen kapcsolati intelligenciához vezet(het).

Ugyancsak nehéz helyzetet és érzelmi sérülést, vagy egyenesen érzelmi „süketséget" okoz a meglévő, a gyermekkel együtt élő szülő(k) elhanyagoló, érzelmileg semleges, közömbös magatartása (Nemes, 1974). Ez utóbbi már a kötődés megtanulásának fázisában is károsíthatja a gyermeket.

Ha a gyermek valamilyen oknál fogva nem kap harmonikus, kiegyensúlyozott érzelmeket, ez a személyiségében nemcsak hiányokat jelenthet, hanem kitermelhet nemkívánatos érzelmeket is. Ez esetben nagyobb az esély a tartós vagy állandósuló harag, düh, megtorlási vágy átélésére, a gyermek oppozíciós, mindennel szembeszegülő viselkedésére.

Lehet-e - a sérülést követő időszakok valamelyikében - segíteni, fejleszteni az interperszonális (önismereti és kapcsolati), valamint az érzelmi intelligenciát? Elvileg igen, hiszen minden intelligencia-fajtát tanulunk is. Az erre a faktorra irányuló tanulási folyamatban azonban nagyon jelentős tényező az, hogy a hiány a gyermek mennyi idős korában jelentkezett és mennyi ideig tartott. Spitz és Wolf (1967, idézi. Mérei és $V$. Binét, 2006) nyomon követő vizsgálatai drámai eredményt mutattak: a hat hónapos korukban anyjuktól elválasztott (az anyák börtönbüntetésüket töltötték) babák az anya nélkül töltött első hónapban kétségbeesetten sírtak, a második hónapban kevesebbet sírtak, inkább nyöszörögtek, lefogytak, a harmadik hónapban elutasítottak mindenféle kontaktust. Hason feküdtek, fejüket fel sem emelve, kifejezéstelen, mimikátlan arccal. Testi, szellemi, lelki fejlődésük megrekedt, s ha az anyátlanság tovább is tartott, letargikus állapotba kerültek. Ha az elválást követő 3-5 hónapon belül újból találkozhattak az anyával vagy olyan felnőttel, aki valóban szerette őket, akkor a tünetek lassan felszámolódtak, a babák fejlődése megindult. Ha az anya vagy egy szerető szívű felnőtt hiánya két évnél tovább tartott, a fejlődés - mind a testi, mind a többszörös intelligencia valamennyi faktora - stagnált, súlyos deficitek keletkeztek, amelyek már nem bizonyultak teljes mértékben felszámolhatónak. Második életévük végére fejlődési mutatójuk mindössze $45 \%$-os volt, vagyis alig érte el egy egyéves gyermek szintjét. (Mindazonáltal tapasztalható még ilyen esetekben is az önfejlődés mint előrevivő tényező.)

A komplex (anyai és apai) szeretet megélése sokféle érzelem tanulására ad lehetőséget, többek között a nagyon fontos erkölcsi érzelmek elsajátítását teszi lehetővé.

Az erkölcsi érzelmek - együttérzés, segítőkészség, felebaráti szeretet, sajnálat, részvét, jóindulat, irigység, féltékenység, részvétlenség, káröröm - jelentős szerepet kapnak a személyiség érzelmi irányultságának fejlődésében, valamint érték/normapreferenciát határoznak meg. Alakítják a személyiség kapcsolati készségeit, intelligenciáját, érzelmeinek sokszínüségét és minőségét, a sikerorientált vagy kudarckerülő magatartást, a stressz, a feszültségek, a konfliktusok kezelését, elviselését. Tudjuk, hogy az öröklődés, a genetikai adományok, a veleszületett, génekbe foglalt lehetöségek kibontakozása az anyai szeretet nyújtotta biztonságban és az ösztönző apai szeretet által közvetített, az apa által (is) képviselt értékek, normák megtanulásában valósul meg. Ezért van jelentősége annak, hogy a több milliónyi veleszületett, kódolt lehetőség közül melyeket „érint meg” a környezet, vagyis melyeket ismer föl, ítél fontosnak, kívánatosnak, a majdani sikeres életvezetés feltételének. 


\section{Nevelés, fejlesztés, környezeti hatások és ezek következményei}

Elgondolkodtató tehát, hogy vajon a gyermek a nevelési preferenciák következménye-e, hogy azzá lesz, akivé lehetne, vagy azzá, akivé nevelése, körülményei lenni engedik/orientálják. A genetikai lehetőségek „megérintése” szükségképpen jelenti egyes képességek preferált, sőt, sok esetben direkt fejlesztését, míg más képességek árnyékban maradva lappangnak vagy elsorvadnak. A beavatkozásnak többféle kockázata is van.

Hadd utaljunk a címre, ami azt sugallja, hogy a mai gyermekek érzelmi élete különbözik a korábbi generációkétól. Hogy ez valós probléma, azt számos pedagógus, szülő és nagyszülő tapasztalata támasztja alá. „Mintha mások lennének a mai gyerekek” (egy nagymama hatéves lányunokájáról), „Egyetlen dolog köti le: az internet” (anya 10 éves fiáról), „Az én fiamat semmi nem érdekli, csak az öldöklős elektronikus játékok” (anya, 14 éves fiáról), „Egész napi küzdelem az élet a gyerekkel, csak ül a számítógép előtt, és ha merészeljük zavarni, olyan goromba, durva, olyan ocsmányul beszél, hogy már nincs is kedvünk hozzászólni” (apa és anya 16 éves fiukról), „Ha békét akarok otthon, hagyom hogy üljön a gép előtt, éjszaka kettőig is. „Kétségbe vagyok esve” (anya, 17 éves fiáról), „Rendkívül erőszakos, agresszív, nagyon durva. Iskolában is verekszik, otthon a kistestvérét üti, fellöki és röhög hozzá. Ha rászólunk, ordítva közli, hogy mindenki ezt csinálja, ez a trendi, mi meg hülyék vagyunk, mert nem értünk a géphez” (anya, 14 éves fiáról), „Rengeteget tanul az internetről, annyi információhoz jut amennyit tíz év alatt sem lehetne összeszedni könyvekből” (apa, 13 éves fiáról), „Gyorsan megírja a dolgozatot magyarból, összeszedi az internetről, de persze másnap egy szót sem tud mondani, nem emlékszik semmire" (anya, 12 éves lányáról), „Nagyon jól használható a gép, sokféle ismeretszerző, ismeretellenőrző programot lehet rárakni, én minden órán használom" (50 éves földrajz-biológia szakos középiskolai férfi tanár). „Mindenre használható a gép, csak az emberi kapcsolatokat nem pótolja, mert a névtelen levelezés nem fejleszti a gyerekekben a másik iránti tiszteletet vagy pláne a türelmet, megértést" (26 éves osztályfőnök, fizika szakos középiskolai férfi tanár), „Nem jó, hogy úgysem találkozunk, azt szólok be amit akarok!” - kegyetlenkednek mindenkivel, durvák, kíméletlenek, és nincs következmény" (32 éves tanárnő, erkölcstant tanít általános iskolában). „Óriási lehetőség, a világlátásuk fejlődik, információk tömege szerezhető meg, olyan véleményekkel, adatokkal találkoznak, amikhez más módon nem juthatnak" (59 éves férfi tanár, természetismeretet tanít általános iskolában).

Ilyen és hasonló vélekedésekkel, véleményekkel sokszor találkozhatunk gyermekeinket illetően. Ezen vélemények többsége azt az aggodalmat fejezi ki, hogy a felnőtt társadalom nem látja biztosítottnak a gyermekek érzelmi-szociális fejlődését, azzal a kiegészítéssel, hogy ismeretek tömegét szerezhetik meg internet használattal a gyermekek. Felelősként az e-technikát jelölik meg. A felnőtt társadalom gyakran tekinti korunk gyermekeit fegyelmezetlen és fegyelmezhetetlen, irányíthatatlan, öntörvényü társaságnak, akik idegenek, szinte ismeretlenek, más tudásuk miatt. Megszületik az Y- (Tari, 2010), majd Z-generáció (Tari, 2011), a „digitális bennszülöttek”, „digitális bevándorlók”, "digitális analfabéták” elnevezés, és ezekkel párhuzamosan a gyakran hangoztatott vélemény: „mi nem érthetjük ezeket a gyerekeket, hiszen nem tudjuk mit olvasnak a neten, más erkölcsöt tanulnak, megtanulják hogy csak elsőnek érdemes lenni, ennélfogva csak elsőnek szabad lenni." Ehhez társul a felnőtt társadalom másik vélekedése, miszerint „hát nem szabad nekik „nem”-et mondani, nem szabad rájuk szólni, megtiltani vagy pláne megbüntetni, mert az a gyerek, akit korlátoznak a szülők, 
az lemarad a versenyben." Úgy tűnik, hogy a felnőtt társadalom igyekszik a digitális kultúrából bűnbakot képezni, áthárítva a gyereknevelés feladatait és felelősségét az e-technikára.

Más oldalról közelítve a jelenséget: a gyerekek több milliónyi genetikai lehetőségei közül melyeket is érinti meg a felnőtt társadalom? A gyerekek nem születnek a digitális kultúra eszközeivel, ezekkel a felnőtt társadalom ismerteti meg őket. Vagyis a genetikai veleszületett lehetőségek közül a felnőtt társadalom az e-technikát kínálva a gyerekek technikai-műszaki intelligenciáját érinti meg, más intelligencia lehetőségek jóval kevésbé, vagy egyáltalán nem kapnak ösztönzést. Valójában a gyerekek intelligencia fejlődését a felnőtt társadalom korlátozza. A számítógépre bízott, a technikát önállóan és profi módon kezelő gyerek - miközben egyre fejlettebb készségekkel használja azt - emberi kapcsolatai, emberi érintkezési lehetőségei és formái mind mennyiségileg, mind minőségileg beszükülnek. Az érzelmi intelligencia fejlődéséhez a másik ember jelenléte, érintése, visszatükröző funkciója szükséges. Az érzelmi intelligencia fejlődése csak emberi, szeretetteljes környezetben jöhet létre.

Joggal merül fel a kérdés: mit tud kezdeni a digitális technika nyújtotta információhalmazzal az érzelmi intelligenciadeficittel élő gyerek, felnőtt? Minthogy a jól/kevésbé jól/hiányosan fejlett érzelmi intelligencia a személyiségben rendező, rendszerező erőt képvisel, ez az információ feldolgozására is kihat. Ezért az információtömeg valamelyest is sikeres feldolgozásához ezt a rendező, rendszerező erőt kell fejleszteni, kihasználva azt, hogy a hét intelligencia faktor egymással összefüggő rendszert alkot, így kölcsönösen támogatják, építik egymást.

\section{Intelligenciafaktorok}

A hét intelligencia faktorról a továbbiakban abból az aspektusból gondolkodunk, hogy ezeknek az elemei mennyiben, milyen mértékben támogatják egymást, illetve az érzelmi intelligencia - mint jelentős koordinátor, mint jelentős információ feldolgozó erő - fejlődését.

\section{Verbális- nyelvi intelligencia (beszéd, írás, nyelvi kultúra, szókincs)}

Segíti az egyént a társadalmi beilleszkedésben, az együttműködésben. Az érzelmi, interperszonális intelligenciának mind az önismereti, mind a kapcsolatteremtési faktorát támogatja.

Fejlesztési lehetőségek (példák):

\begin{tabular}{|l|l|}
\hline Családban/óvodában & Iskolában \\
Aktív, beszélő környezet biztosítása & \\
A gyermek beszédre ösztönzése & Tantárgyakban, kiemelten: irodalom, \\
Szójátékok & nyelvtan, drámapedagógia \\
Szinonimagyűjtés, scrabble & \\
Mesehallgatás, meseköltés & \\
Társasjátékok & \\
\hline
\end{tabular}

Matematikai-logikai intelligencia (érvelés, ok-okozati összefüggés, számok világa, rendszere)

Ok-okozati összefüggések felfedezése segítségével, valamint a viszonyítás, a relativitás érzékeltetésével támogatja az érzelmi intelligencia kapcsolatépítési faktorát. 
Fejlesztési lehetőségek (példák):

\begin{tabular}{|l|l|}
\hline Családban/óvodában & Iskolában \\
Napirend & Tantárgyakban, kiemelten: \\
Időpontok & matematika, algebra, geometria, sakk \\
Időtartam & \\
Szabályok objektivitása & \\
Sakk, malomjáték, amőba & \\
Rubik-kocka &
\end{tabular}

Vizuális-téri intelligencia (a látvány esztétikuma, a környezet téri elhelyezkedése, a tér ésszerü használata, berendezése, színek és formák harmóniája)

Az érzelmi intelligencia önismereti faktorát támogatja, elvezet az önuralom, önszabályozás alakulásához: a saját test érzékelése a térben, alkalmazkodás a téri lehetőségekhez, téri irányok és relációk tanulása. A térben a személyközi távolságok szabályozása támogatja a kapcsolatteremtés készségét.

Fejlesztési lehetőségek (példák):

\section{Családban/óvodában}

Játékok a térben (dodzsem, bújócska, fogócska, adj király katonát, hintázás, testnevelési játékok)

Szoba/lakás rendezés

Kertrendezés/tervezés

Festés, rajzolás, agyagozás, barkácsolás,

papírhajtogatás

\section{Iskolában}

Játékok (bújócska, fogócska, szembekötősdi)

Játéktárgyak keresése („vak”tapintással)

Rubik-kocka

Tantárgyakban, kiemelten: földrajz (térképrajzolás, földgömb használata), rajz (festés, rajzolás,

agyagozás, szoborkészítés, színek, színárnyalatok, formák megkülönböztetése, formák elhelyezése a térben), technika (modellszerelés, tárgyak alkotása)

Testi-kinetikus intelligencia (testi-mozgásos tevékenységek, a testi mozgások gazdaságos, összerendezett használata, a kéz finommotorikája)

Érzékelés, észlelés, mozgásirányítás, mozgáskoordináció, testi szenzációk érzékelése, a tárgyi és perszonális ingerek pontos értelmezése segíti az önismeretet, önszabályozást, önkontrollt és az emberi kapcsolatok értelmezését. Ezzel támogatja az érzelmi intelligencia önismereti és kapcsolati faktorát.

Fejlesztési lehetőségek (példák):

Családban/óvodában
Közös sportolás
Mozgásos játékok: úszás, futás,
sétálás, labdajátékok
Kirándulás, hegymászás

Iskolában

Tantárgyakban, kiemelten:

testnevelés, tánc, ének-zene

Zenei-auditív intelligencia (hangok, ritmus, hangszín, beszédritmus)

Érzékelés, észlelés: hangok, ritmusok érzékelése, reprodukálása, hanganalízis, uralom a hangképzés felett, ritmusosság felismerése, szekvenciák alkotása fejlesztik az önismeretet, a társas kapcsolatokat (mint az érzelmi intelligencia elemeit), valamint az iskolai tanulási képességeket. Ez utóbbi képességcsoport a verbális-nyelvi intelligencia faktorral kölcsönhatásban (írás, olvasás tanulás, szókincsbövülés révén) támogatja a társas kapcsolatok fejlődését. 
Fejlesztési lehetőségek (példák):

\begin{tabular}{|l|l|}
\hline Családban/óvodában & Iskolában \\
Együttes éneklés & Tantárgyakban, kiemelten: ének, tánc, \\
Énekes játékok & népi játékok, drámajáték \\
Auditív emlékezet játékok & \\
Zenehallgatás & \\
Mondókázás &
\end{tabular}

Interperszonális intelligencia: önismereti és szociális, kapcsolati intelligencia

Saját vágyak ismerete, befogadás/elfogadás iránti vágy, empátia megélése, tolerancia, érzelemindította kapcsolatok keresése az együttlét öröméért, szeretet adása/elfogadása, igény a konfliktusok kezelésére, tanulás önmagáról, otthoni tevékenységekben, kudarctürés, kitartás. A szeretet, a másik tiszteletének tanulása mintakövetéssel, a konfliktuskezelés mintázatainak elsajátítása, erkölcsi értékek és érzelmek tanulása (megbocsátás stb.), felelősségvállalás. Ezek támogatják az interperszonális/érzelmi intelligencia minden tényezőjét.

Fejlesztési lehetőségek (példák):

Családban/óvodában

Házimunka

Állatok örökbefogadása, gondozása

Gondoskodás idősekről, fiatalabb gyerekekről

Kirándulás állatkertbe

Adományozás, gyűjtés mások megsegítésére

Családi ünnepek

\author{
Iskolában/óvodában \\ Önismereti játékok \\ Önismereti körök \\ Társasjáték \\ Ajándékozás \\ Születésnapok ünneplése \\ Társadalmi segítő tevékenység \\ Környezetrendezés
}

Metakognitív intelligencia (foglalkozás önmagammal: ki vagyok én, honnan jövök, hová tartok, mi a dolgom; filozófiai kérdések: mi a helyes, mi a jó, mi a világ, van-e rendező elv, mi az ember dolga a világban)

Az egyes intelligencia faktorok integrálása, magasabb szintre, magasabb minőségre emelése: önismeret erősítése, az önismeret elemeinek absztrahálása, pszichológiai, filozófiai, társadalmi kérdések és válaszok kidolgozása. Eszközei: az introvertált létezés (a befelé fordulás, önmagunkra, lelki folyamatainkra figyelés), a gondolkodás. Ezek mindegyike az interperszonális intelligenciát fejleszti, ugyanakkor a metakognitív intelligencia fejlettsége visszahat az összes többi intelligencia faktorra.

Fejlesztési lehetőségek (példák):

Családban

Beszélgetések

Élettervek készítése (mire vagyok már most képes, illetve miben kell még fejlődnöm, valamint mit

csinálok, milyen leszek 5-10... év múlva)
Iskolában

Bizalomjátékok

Társasjátékok

Tantárgyakban, kiemelten: filozófia, erkölcstan,

hittan, pszichológia

Az interperszonális/érzelmi intelligencia fejlesztésében családnak és az iskolának sokféle feladata, felelőssége és számtalan lehetősége van. A folyamatban kiemelt jelentőséggel bír a felnőttek mintaadó magatartása, az együtt töltött minőségi idő, beszélgetések, közös élmények, a spontán nevelési helyzetek adta lehetőségek kihasználása. 


\section{Szeretetnyelv - mint lehetőség}

Családban az anyai/apai szeretet, az elfogadás, a gyermek testi, lelki egészségének, „well-being”-jének megteremtése/alakítása/fenntartása, a tudatos mintaadó magatartás kontrollálása a feladat. Meg kell ismerni a családtagok szeretetnye/vét. Mindenkinek van preferált, érzékenyen lereagált, őt különösen megérintő érzelme. A szeretetnyelv-elmélet kidolgozása (Chapman, 2011) közelebb vihet minket a gyermekeinkkel való bánásmód helyes megválasztásához. A szerző öt szeretetközlési lehetőséget kínál: elismerő szavak, minőségi idő, ajándékozás, szívességek, testi érintés. Természetesen ezekből egy embernek lehet több érzékenységi pontja is. Ugyanígy minden embernek vannak szeretet-kifejezési formái is. A gyermekek optimális fejlődése érdekében érdemes megfigyelni, milyen megnyilvánulásokat értelmez a gyermekünk szeretet-közlésnek.

Elemezzük az öt szeretetnyelvet, hogy megfelelöen tudjuk alkalmazni azokat!

Elismerő szavak (mint verbális/nyelvi intelligencia faktor részei): dicséret, megerősítés, ösztönzés, biztatás. Hogy ezeket jól használjuk, ismernünk kell a saját és a másik ember kommunikációját. Vajon kommunikációnkban a kérés, kérdezés, a tanácsadás, a felszólítás, az utasítás, a követelés, a magyarázat vagy a fenyegetés dominál? Vajon a másik személy ezek közül melyiket érti leginkább? Metakommunikációnk megerősíti, megsemmisíti, vagy súlytalanná teszi verbális közléseinket?

Minőségi idő: az együtt töltött idő dinamikája, tartalma és időtartama határozza meg. Jellemzője: csak az adott másik emberrel fenntartott kommunikáció - telefonálás, tévézés, internetezés - nélkül. Lényege: tégy félre mindent, csak a másikkal törődj!

Ajándékozás: tárgyak és önmagunk odaajándékozása egy időre a másiknak (ünnepek, születésnap).

Szívességek: megtenni általunk nem kívánt dolgokat, azért, hogy a másik érezze szeretetünket.

Testi érintés: a bizalom, a szeretet, az intimitás egyik legfontosabb kifejezése a másikat úgy érinteni, ahogyan az számára a legjobb. Alapja az a felismerés, hogy teljes személyiségünk a testünkben van, és azon keresztül jelenik meg. Ezért fontos, hogy mi történik a testünkkel, hogy hogyan bánik a környezet a gyermek testével. A testi érintésnek olyan hihetetlenül nagy szerepe van az emberi életben, hogy hiánya rendkívül súlyos személyiségzavarokhoz vezet.

\section{Esetismertetés}

Két esetet ismertetünk a szerző többéves iskolapszichológusi tapasztalatai alapján. A két eset szemléltetése az eddigieknek. Mintegy esszenciája, összegzése azoknak a gyermeki élethelyzeteknek, gyermeki fejlödési folyamatoknak, amelyekkel gyakran találkozunk iskolákban, óvodákban. Jó és kevésbé jó szülők viszonyulnak a gyerekeikhez oly módon, hogy önmagukat - különböző okokból, különböző mértékben - kivonják a gyerekeikkel való személyes, intim kapcsolatból, rábízva őket más felnőttekre, esetenként technikai eszközökre.

\section{A) ESET:}

I. K. hétéves, első osztályos kisfiú. Panasz: türelmetlen, ingerlékeny, tanítási órán bekiabál, órán és szünetben verekszik, dühöng, tör-zúz, összetépi a többiek füzetét, könyvét, összetapossa a krétákat és filctollakat, obszcén szavakat ordít. 
Feltűnően szép gyerek, ápolt, gondozott reggelente. Szókincse életkorra jellemző, képzési vagy ritmushiba nem észlelhetö. Beszédkésztetése négyszemközti helyzetben jó, szívesen kommunikál.

Magatartásával kapcsolatban belátó-szégyenkező-dacos attitüdök észlelhetők, többnyire elfogadja a felnőttektől eredő kritikát, időnként tiltakozik, dühöngése okát más gyerekek viselkedésére adott, jogos reakcióként értelmezi.

Tanítási órákon szívesen, gyorsan, eredményesen dolgozik, főként matematikai és müszaki-technikai dolgok érdeklik, testnevelés órán nekivadulva rohan, felmászik a kötélre, bordásfalra, onnan ugrik rá lent ülő gyerekekre.

Olvasni óvodásként tudott, írásképe változó: a „Nagyon szép, szabályos, pontos”megállapítástól a „Rémes, mi van veled?” kérdésig tartó tanítói értékelések tarkítják a munkáit. Füzetei bekötve, a lapok felgyűrve, kezdetben tiszta lapok, később pecsétes, maszatos lapok sorakoznak.

Iskolába pontosan érkezik, az apa hozza, ruházata reggel tiszta, rendezett. Napközis, az apa fél ötkor érkezik érte, akkorra a gyerek „elhasználódott”; ruhája lóg, pecsétes a napi étkezésektől, cipőjét papucsként használja, keze, arca piszkos, maszatos.

Apját mindig örömmel fogadja, de visszaszalad folytatni a játékot, beszélgetést a többi gyerekkel, s csak a napközis pedagógus többszöri felszólítására, biztatására („holnap is játszhatsz”) hagyja el a termet.

Családi háttér: I. K. egyetlen gyerek, a szülők a fiú hároméves korában elváltak, a gyerek az anyánál maradt. Eleinte igen ritkán, havonta egyszer találkozott az apával, később egyre több időt töltött nála, alkalmanként három-négy hetet is, az anya külföldi munkavállalása miatt. Az anyai nagymama az apánál lakik.

Családrajzán ő az A4-es lefektetett lap közepén áll, tőle egyenlő távolságban, két oldalán az apa és az anya. Az apa kézfeje ökölnek látszik (verbálisan megerősíti ezt „mert apukám erős”), az anyának a gyerek felőli karján nincs kézfej, a másik oldalán igen, precízen megrajzolt, öt ujjal.

A szülőkkel folytatott beszélgetések során kiderül, hogy egyik szülőnek sem sikerül szóra bírnia a gyermeket, válaszai konzekvensen a „Semmi nem volt, miért?” és a „Hagyjál békén, utállak!” közlésekre szorítkoznak. Otthoni időtöltése: „gépezik, tablettel játszik, egész este, néha éjszaka is”. Barátai nincsenek, nem jár senkihez, hozzá sem jön senki. A szülöknek egyáltalán nincs baráti körük, „nem érünk rá, dolgozunk"- mondják. Az apai nagymama két-három hetente látogatja őket.

$A z$ anya rendszeresen két-három hónapot tölt külföldön, diplomájának megfelelő munkakörben dolgozik, közben három hetente hazajön, „látni a gyereket”. Ily módon a gyerek az apánál az anyai nagymamánál él, apjától kissé tart, a nagymama türelmével, szeretetével visszaél „hülyére veszi az öreglányt” - mondja az apa mosolyogva.

Iskolai megfigyelések, valamint vizsgálatok alapján a következők állapíthatók meg: magas értelmi intelligencia, igen rossz stressz- és konfliktuskezelési gyakorlat, az érzelmek közül főként düh észlelhető, az általános magatartás nyugtalan, ingerült, támadó. A figyelmi képesség érdeklődés esetén jó, a teljesítmény ehhez igazodik.

Jó teljesítményét a gyerek zajosan ünnepli, azonnal összehasonlítja másokéval, kinyilatkoztatva: „I am the best” - ilyenkor mellét verdesi, ugrál. Ugyanakkor teljesen bizonytalan önmaga megítélésében, szorongva lesi, hogy munkája megfelelő-e, de nem kér visszajelzést vagy segítséget, rajzos-írásos munkáit kezével takarja.

Képtelen várakozni, utasításokat nem hallgat végig, kapkodva belekezd valamilyen feladatba, de a számára érdektelen feladatokat vagy el sem kezdi, vagy - a legkisebb nehézség esetén - abbahagyja, ellöki magától, éneklő hangon közli „uuunooom, uuunalmaaas". 
Alkalmazott javaslatok, technikák, eredmények:

\begin{abstract}
Családban:
Tanácsadás, értelmezés a szülőknek:

Nem a düh, a harag, és az ezek nyomán járó extrém viselkedés a probléma, hanem a mögöttük lévő súlyos deprivációs szorongás. A gyereknek az a félelme, hogy az anyjának nem eléggé fontos (hiszen az anya ismétlődően, rendszeresen „elhagyja” őt). Ezt a szorongást javasolt az anyai attitűd módosításával, az anya jelenlétének fokozásával kezelni. A gyerek dühét, haragját mint a világ felé történő jelzést - nem elfojtani kell, hanem hasznos tevékenységbe csatornázni, kanalizálni.
\end{abstract}

(Interperszonális intelligencia, verbális intelligencia fejlesztése a szülőkben.)

\section{Változások:}

- Az anya kevesebb időt tölt külföldön egy-egy alkalommal, amit lehet, számítógépen intéz itthonról.

- A gyerek vízilabda edzésekre jár heti két alkalommal (testi - kinesztéziás intelligencia fejlesztése: önkontroll a test fölött, transzfer hatás a magatartás rendezésében).

\section{Eredmények:}

- A kisfiú három hónap alatt egyre kevesebb dührohamot produkált (ezek nem szüntek meg teljesen, fellépésük az anya elutazásait kísérték).

- Két fiú osztálytársa barátkozik vele, együtt járnak modellezni.

- Kevesebb fegyelmezetlenség a tanítási órákon, szünetekben.

\section{Várható további fejlődés:}

- A gyerekben tudatosul viselkedési anomáliájának oka, növekszik önkontrollja, önfegyelme. Amennyiben az anya és az apa betartják a gyerekkel való együttlét irányelveit, indulatai elaborálódnak.

\section{Iskolában:}

Tanácsadás, értelmezés a pedagógusoknak: A gyereknek nem az iskolával van „baja”, de mivel ott tölti napjainak nagy részét - a tünet ott is megnyilvánul. Mivel alapvető érzelmi, biztonsági szükségletében frusztrált, ezért nagyon szorong. Ebből a szorongásból már-már patológiás dührohamokkal tör ki. Szorongását oldandó dühét, haragját elaboráló foglalkozás javasolt. (Az interperszonális intelligencia megtámogatása, értő attitűd alakítása a pedagógusokban.)

\section{Változások:}

- $\quad A z$ iskolában befogadták egy már működő drámapedagógiai csoportba, ahol a szorongásagresszió legális kiélését illetve egyensúlyának létrehozását és ennek nyelvi kifejezését próbálgatja (interperszonális intelligencia: az érzelmek, indulatok verbalizálása, valamint ezeknek legális, önkontrol alatt történő kifejezése).

- Iskolai hittanra beíratják, ahol mód nyílik a számára problémás „szeretnek-e engem eléggé, fontos vagyok-e eléggé" kérdésekről beszélgetni (metakognitív intelligencia támogatása).

- Heti egy alkalommal részt vesz az iskola modellező szakköri foglalkozásain, ahol feltűnően kreatívan, eredményesen dolgozik (vizuális, kinesztéziás intelligencia fejlesztése kreatív tevékenységben).

\section{Eredmények:}

- E gyerek toleránsabb viselkedése észlelhető a drámajátékokban.

- A testi-kinesztéziás önkontroll fejlődése, kanalizálva mások számára is értékelhető produktumba.

További lehetőségek:

- Népi játékokban történő szerepvállalás (pl. húsvétolás, betlehemezés).

Összegezve: kiemelten fontos az érzelmi biztonság kiépítése, mind otthon, mind az iskolában. Ennek érdekében a tünetek értelmezésére valamint tanácsadásra van szükség a szülök és a pedagógusok számára. Ezáltal változik a felnőtteknek a gyermekre irányuló attitűdje; bánásmódjuk értő és kevésbé indulattelt lesz.

Továbbá: verbális-nyelvi, testi-kinesztéziás, interperszonális, metakognitív intelligenciát fejlesztő tevékenységeket tettünk lehetővé, olyanokat, amelyek - fejlesztő, a személyiséget rendező/korrigáló funkciójuk mellett - örömmel töltik el a kisfiút.

\section{B) ESET:}

K. A. második osztályos kislány. Panasz: nagyon sokat és sokszor sír, otthon is, iskolában is. Iskolai teljesítménye hullámzó, figyelme „olyan, mintha mindig befelé figyelne magára, ezért nem hallja amit mondunk" (anya és pedagógus). 
Szép, ápolt kislány, rendezett külsővel, enyhe túlsúllyal.

Beszédfejlettsége megfelelő, írásképe változó, olvasási készsége kiváló, matematikai teljesítményei közepes-jó szintűek. Mozogni, mozgásos játékokban részt venni nem szeret, inkább üldögél. Két barátnője van az osztályban, a kapcsolatuk ambivalens, állandó vetélkedésben, harcban állnak, de ragaszkodnak egymáshoz. A pedagógus értékeléseit látszólag elfogadja, tudomásul veszi, csakhogy azonnali sírással reagálja le, még a kedvező véleményt is.

Családi háttér: kétszülős család, a többszintes családi házban velük él az anyai nagymama is. Egy testvére van, pár hónapos kisfiú, vele az anya GYES-en van, az apa késő este ér haza, „sokat dolgozik, mindig dolgozik, anya nem ér rám, mert van a kistestvérem" - mondja a gyerek.

Családrajz: a lefektetett A4-es lap közepén, mintegy a lap egyharmadát lefedve, TV és számítógép áll egy asztalon, egyetlen székkel. Személyek a lap két oldalán fennmaradó sávban vannak, valamint középen lent, egészen a lap szélére préselve. A bal oldali sávban áll az anya, kezében a kisbabával, öltözékük egyformán rózsaszín és pink, hajuk szőke. A jobb oldali sávban áll az apa, kezében teniszütő. Öltözéke szürkés sportruha és cipő, haja nincs. A lap aljára préselve egy gyerekfigura, kissé testes, kövérkés, grafittal besatírozott ruhában, haja foltos. „Ez én vagyok, megyek a géphez”. A rajzon legkidolgozottabb a TV és a számítógép.

Értelmes kislány, beszükült érzelmekkel, érzelmi válaszokkal. Anya és a kislány egybehangzóan elmondják, hogy náluk „nem divat a sok beszéd” (anya), illetve „nem szoktunk beszélgetni, mit mondjak én nekik” (a gyerek). Valamint „apával birkózunk, ha időben jön haza, de én mindig sírok, mert én veszítek. Igaz, akkor is sírok, ha apa nem jön haza”. Kérdésre: „Nem tudom, miért kell annyit sírnom, de sírok. Nem tudom, mit szeretnék - semmit. Vagyis hogy anya legyen velem is kedves, nekem is kell egy anyuka, apa meg ne győzzön le mindig".

Alkalmazott javaslatok, technikák: 


\section{Családban:}

Tanácsadás a szülőknek (a gyerek viselkedésének értelmezése):

Valójában gyászmunka történik: az anya kizárólagosságának elvesztése fölötti bánat, szomorúság, tehetetlen kétségbeesés zajlik a gyerekben, keveredve lelkiismeret-furdalással, amiért nem képes eleget tenni a szülői elvárásnak, hogy megfelelően szeresse a kistestvért. Verbalizálni nem képes a problémáit, ehelyett passzív-depresszív kedélyállapot jellemzi. Az apával való vad birkózás nem pótolja számára a hiányzó anyai ölelést. A gyerek elveszítette korábbi, biztonságos családi szerepét és státuszát, ehelyett kell törekedniük a szülőknek a megváltozott helyzethez igazodva egy új, más minőségü és tartalmú szerep/ státusz kialakítására. (Verbális intelligencia, interperszonális intelligencia fejlesztése a szülőkben és a gyerekben.)

\section{Javaslat:}

- Otthoni - az anyával történő - meseköltés, bábozás, együttes mesehallgatás (ezek segítséget jelenthetnek a gyermek számára érzelmeinek felismerésében, identifikálásában).

- Hangsúlyozottan éljék meg együtt az intim, bensőséges családi ünnepeket - például a szük család külön ünnepeljen születés - névnapokat, kiterjesztett ünneplés csak ezek után legyen (testi, kinesztéziás, társas intelligencia).

- Olyan mozgásformák ösztönzése, melyekben görcsössége, merevsége, koordinációs gyengesége oldódhat; emellett módot adnak az anyával való együttlétre, saját és az anya érzelmeinek felismerésére, tudatosítására. Ilyen mozgásformák lehetnek: hintázás, úszás, énekes játékok, spontán tánc zenére.

- Beszéljék meg együtt, milyen szerencse és boldogság, hogy ők már nyolc éve együtt vannak, s ez mennyi öröm és élmény mindannyiuknak.

(érintéses, kinesztéziás, identifikációs, interperszonális intelligencia folyamatok)

\section{Eredmények:}

A kislány a számára előnyösen változó környezetben eleinte gyanakodott, majd fokozatosan vált bizakodóvá. Kezdetben nehezen, de elfogadta az anya közeledését, s egy idő után hitt is annak őszinteségében. A szülők csodálkozására nem követelt tévézést, mintha ez nem is érdekelte volna. Iskolában sikeresnek kezdte érezni magát, a pedagógus feszültségmentes bánásmódja és a tánc is segítette ebben. Otthon időnként sírdogál este, ilyenkor sajnálja magát azért hogy nem sikerül még jobban viselkednie.

\section{Várható további eredmények:}

A gyerek személyiségfejlődése feltehetően kevesebb érzelmi trauma, elhagyatottság-érzés, gyászmunka keretében fog zajlani. Különösképpen akkor, ha kialakítja a családon belül a számára új szerepet és státuszt. Abban nem lehetünk egészen bizonyosak, hogy további érzelmi válságok nem érintik ezt a fejlődést, csak abban bízhatunk, hogy az anya „visszatanulja” anyaságát ehhez a gyermekéhez, valamint hogy ez az értelmes kislány elfogadja és használja az érzelmi intelligenciája fejlödéséhez feltétlenül szükséges érzelmi tudatosítást, s ezzel egyidejüleg megtanulja felismerni és megélni életének örömteli eseményeit is.

\section{Iskolában:}

Tanácsadás a pedagógusoknak (a tünetek értelmezése, az értő interperszonális intelligencia fejlesztése):

- A kislány hangulatingadozása, kedélyállapotának romlása, gyakori sírása a megszokott családi állapot elveszítéséből fakad.

- A pedagógus nyújtson megbízható, kiszámítható biztonságot, fogadja el - kommentárok nélkül - a gyerek viselkedését.

- Amennyiben a gyerek igényli és elfogadja, sok érintéssel tegye hitelessé kapcsolatuk szoros voltát. (Biztonságnyújtás, szeretetnyelv alkalmazása, interperszonális intelligencia fejlesztése.)

\section{Eredmények:}

- A pedagógus felszabadult a nyugtalanító érzés alól (hogy talán ő is hibás a tünetek miatt), ezért a korábbinál jóval kiegyensúlyozottabban bánik a gyerekkel.

- A kislányt befogadták az iskolai táncszakkörbe, ahol kissé esetlenül, de nagy örömmel táncol. 
Összegezve: nagyon fontos a családi változások esetében az egyes gyermekek szerepének, státuszának megváltozását felismerni és kezelni. A szülőknek fel kell figyelniük a gyermek magatartásának, teljesítményének megváltozására és törekedniük kell egy új minőségű kapcsolat, intimitás, érzelmi helyzet kialakítására. Az iskola ebben kiválóan támogathatja a gyermeket és a szülőket, amennyiben érti a gyermek megnyilvánulásai mögött rejtőző üzeneteket, segélykérést.

Mindkét esetben érzékelhető, hogy az optimális személyiségfejlődéshez szükséges a biztonságérzet, az anya feltétlen és megingathatatlan, illetve az apa ösztönző szeretete. Ezek időleges vagy tartós hiánya, vagy a gyermek számára érzékelhetetlenné válása komoly torzulásokat okozhat; ugyanakkor a segítő - támogató - értő, a helyzeteket jól értelmező viszonyulás megfordíthatja, helyrehozhatja, vagy legalább enyhítheti a következményeket. Ezek értékei mindkét esetben tapasztalhatók

Összefoglalóan megállapíthatjuk, hogy ezek a gyerekek értelmesek, okosak, de érzelmi bázisuk rendkívül beszükült, érzelmeiket nem tudják adekvát módon kifejezni. Képtelenek viselkedésük másokra gyakorolt hatását, azokat az érzelmeket, melyeket környezetükben keltenek, anticipálni. Mindkét gyereknél - s minden hasonlóan fejlődő gyermeknél - tapasztaljuk, hogy jó értelmi képességeik nem elegendőek a környezetük által „bejósolt” és elvárt teljesítmények, viselkedés, alkalmazkodás megvalósítására.

Itt válik a gyakorlatban kitapinthatóvá mindaz, amit elméletileg tudunk; hogy jól fejlett érzelmi intelligencia, széles spektrumú érzelmi élet nélkül sikeresség, boldogulás és eredményesség aligha érhető el. Az esetekből azt is láthatjuk, hogy az érzelmi/ interperszonális intelligencia deficitjét nem tulajdoníthatjuk kizárólag a digitális kultúra elterjedésének, ebben sokkal fontosabb szerepet játszik a személyességnek, a gyerekkel való együttlétnek a szegényessége vagy hiánya. Rávilágít a tapasztalat arra is, hogy az intimitás, a személyes odafordulás, a gyermek szeretetnyelvének ismerete nem váltható át mégoly érdekes, izgalmas tevékenységekre sem, és nem is helyettesíthető velük.

\section{Konklúziók}

- Tapasztalataink és ismereteink alapján azt mondhatjuk, hogy vannak különbségek a generációk érzelmi élete, érzelmi fejlődése között, de ezek egzakt módon nem vethetők össze, hiszen senki nem mérte fel egyes nemzedékek érzelmi életét. Ám az, hogy érzékelhető különbségek vannak, nem vitatható.

- Az érzékelhető változásoknak multikauzális háttere van: a megváltozott szülöi szerepfelfogás, a szülők gyakori kivonulása a gyermek érzelmi életéből, az értelmi fejlődés elősegítésének preferálása az érzelmi élet fejlesztésével szemben, a gyerekre zúduló információk, amelyek között gyakori az agresszív tartalom, valamint az információk, ismeretek feldolgozásának teljes vagy részleges hiánya mind hozzájárulnak a gyermek érzelmi életének alakulásához. Külön is érdemes elgondolkodnunk a szülők között elterjedt vetélkedésről: ki viszi több különórára, külön foglalkozásra már az óvodáskorú gyermeket is, ezzel azt a képzetet keltve a gyerekben, hogy az élet kizárólag versenyből áll, ahol az így megszerzett tudások mérkőznek egymással, és csak a győztesnek van élettere. A tudások versenyében - sokszor kifejezett szülői sugalmazásra - minden eszköz megengedett. Ezt a szemléletet hangsúlyozott érzelmi intelligencia fejlesztéssel lehet és kell ellensúlyozni.

- Az iskolának/óvodának sajátos lehetőségei vannak a gyermekek érzelmi életének, az érzelmi/interperszonális intelligenciának a fejlesztésében. Tanulási, játéktevékenységbeli lehetőségeken kívül a pedagógusok konzekvensen mintaadó, érzelmeket tudatosan vállaló és közvetítő, önkontrollal rendelkező, mások - a gyerekek - érzelmeit megértő, azokat tiszteletben tartó személyisége a kulcs. 
- A családok felelőssége és lehetőségei másképp nyilvánulnak meg, a gyermek életének egészen korai szakaszában jelentkeznek. A gyermeknek sugárzott anyai és apai szeretetben, a gyermek szeretetnyelvének használatában, értékek, normák közvetítésével, következetes mintaadásban, a gyerekkel való folyamatos kapcsolatban testesülnek meg. E folyamatok optimális esetben az intézményekkel összhangban, velük egyeztetve zajlanak, amelyekben mind a családnak, mind az iskolának/óvodának ismernie kell saját feladatait és kompetenciáját.

Ha azt szeretnénk, hogy gyermekeink boldog emberek legyenek, alkotóképes új generációt alkossanak, akkor felkínálni és biztosítani kell számukra sok és sokféle interperszonális kapcsolatot, meg kell tanítanunk nekik az egyes tevékenységek közötti arányosságra, egyensúlyteremtésre törekvést. Nyilvánvaló, hogy ebben a nagy feladatban a felnőttek egészséges személyisége fontos szerepet játszik. A következő generációk testi-lelki egészségnek megalapozása és folyamatos karbantartása a gyermeket nevelő mai felnőttek felelőssége.

\section{Irodalom}

Binet, A. and Simon, T. (1905; reprinted 1916). New methods for the diagnosis of the intellectual level of subnormals. In A. Binet \& T. Simon (Eds.), The development of intelligence in children. Williams \& Wilkins, Baltimore.

Chapman, G. (2011): Egymásra hangolva. Harmat Kiadó, Budapest.

Felsman, J.K. and Vaillant, G.E. (1987): Resilient Children as Adults: A 40-year study. In: Anthony, E.J.and Cohler, B.J. (Eds.): The Invulnerable Child, Guilford Press, New York.

Fromm, E. (2001): A rombolás anatómiája. Háttér Kiadó, Budapest.

Fromm, E. (2012): A szeretet müvészete. Háttér Kiadó, Budapest.

Gardner, H. (1983): Frames of mind: the theory of multiple intelligence. Basic Books, New York. Gardner, H. (1999): Intelligence Reframed. Basic Books, New York.

Goleman, D. (2008): Érzelmi Intelligencia. Háttér Kiadó, Budapest.

Hidas György, Raffai Jenő és Vollner Judit (2013): Lelki köldökzsinór. Helikon Kiadó, Budapest. Mérei Ferenc és V. Binét Ágnes (2006): Gyermeklélektan. Medicina Könyvkiadó, Budapest Nemes Lívia (1974): Pszichogén tünetképződés kisgyermekkorban. Akadémia Kiadó, Budapest. Pulay Klára (1997): A kötődésről és az anya hiányáról. In: Bernáth László és Solymosi Katalin (szerk.) Fejlödéslélektani olvasókönyv. Tertia Kiadó, Budapest.

Tari Annamária (2010): Y generáció. Jaffa Kiadó, Budapest.

Tari Annamária (2011): Z generáció. Tercium Kiadó, Budapest. 